\title{
Interleukin 15 Is Produced by Endothelial Cells and Increases the Transendothelial Migration of T Cells In Vitro and in the SCID Mouse-Human Rheumatoid Arthritis Model In Vivo
}

\author{
Nancy Oppenheimer-Marks, Ruth I. Brezinschek, Mansour Mohamadzadeh, ${ }^{*}$ Randi Vita, and Peter E. Lipsky \\ Rheumatic Diseases Division of the Department of Internal Medicine and the *Dermatology Department at the University of Texas \\ Southwestern Medical School, Dallas, Texas 75235-8577
}

\begin{abstract}
The capacity of endothelial cells (EC) to produce IL-15 and the capacity of IL-15 to influence transendothelial migration of $T$ cells was examined. Human umbilical vein endothelial cells expressed both IL-15 mRNA and protein. Moreover, endothelial-derived IL-15 enhanced transendothelial migration of $T$ cells as evidenced by the inhibition of this process by blocking monoclonal antibodies to IL-15. IL-15 enhanced transendothelial migration of $T$ cells by activating the binding capacity of the integrin adhesion molecule LFA-1 (CD11a/CD18) and also increased T cell motility. In addition, IL-15 induced expression of the early activation molecule CD69. The importance of IL-15 in regulating migration of $T$ cells in vivo was documented by its capacity to enhance accumulation of adoptively transferred human $T$ cells in rheumatoid arthritis synovial tissue engrafted into immune deficient SCID mice. These results demonstrate that EC produce IL-15 and imply that endothelial IL-15 plays a critical role in stimulation of $T$ cells to extravasate into inflammatory tissue. (J. Clin. Invest. 1998. 101:1261-1272.) Key words: cytokine $\bullet$ motility $\bullet$ adhesion $\bullet$ LFA-1 $\bullet$ CD69
\end{abstract}

\section{Introduction}

The vascular endothelium plays an essential role in a number of physiologic processes involved in the maintenance of hemostasis, inflammatory responses, and immune function (1). Among the functions of the endothelium during immune and inflammatory responses is the facilitation of the transendothelial migration of $\mathrm{T}$ lymphocytes into perivascular tissues. This process involves specific receptor-mediated binding of distinct $\mathrm{T}$ cell subsets to endothelial cell $(\mathrm{EC})^{1}$ surfaces followed by active receptor-dependent transmigration of some of the bound $\mathrm{T}$ cells (2). Although all of the events involved in transendothelial migration have not been delineated completely, the process is known to involve the activity of cell sur-

Address correspondence to Dr. Nancy Oppenheimer-Marks, Department of Internal Medicine, The University of Texas Southwestern Medical Center at Dallas, 5323 Harry Hines Boulevard, Dallas, TX 75235-8577. Phone: 214-648-7987; FAX: 214-648-3011; E-mail: nmarks@mednet.swmed.edu

Accepted for publication 18 December 1997.

J. Clin. Invest.

(C) The American Society for Clinical Investigation, Inc. 0021-9738/98/03/1261/12 \$2.00

Volume 101, Number 6, March 1998, 1261-1272

http://www.jci.org face adhesion receptors, including the receptor pair leukocyte function-associated antigen (LFA)-1 (CD11a/CD18) and intercellular adhesion molecule (ICAM)-1(CD54), that mediate progressive adhesions formed between EC and migrating $\mathrm{T}$ cells (3).

Soluble mediators also have been demonstrated to play important roles in $\mathrm{T}$ cell extravasation into tissue. Certain cytokines produced in perivascular tissue, such as $\mathrm{TNF}_{-} \alpha$ and IL-1 $\beta$, facilitate the transendothelial migration of $\mathrm{T}$ cells by stimulating endothelial adhesion receptor expression, resulting in increased $\mathrm{T}$ cell binding $(4,5)$. Chemokines, such as macrophage inflammatory protein (MIP)- $1 \alpha$, MIP-1 $\beta$, IL- 8 , and monocyte chemotactic protein- 1 may serve a chemotactic role, and increase $\mathrm{T}$ cell migration directly, possibly by stimulating the activity of integrin adhesion receptors to strengthen $\mathrm{T}$ cell binding to EC and/or to mediate migration (6-9). Most chemotactic factors have been shown to be produced by cells in perivascular tissues and are thought to exert their activities by establishing chemotactic gradients from tissue to the EC surface and thereby attracting migrating cells. Others, including IL-8 and monocyte chemotactic protein-1, are also known to be produced by EC and may, therefore, directly influence $\mathrm{T}$ cell-EC interactions $(10,11)$. These latter findings imply that part of the endothelial mechanism to regulate $T$ cell extravasation into tissue may involve the elaboration of factors that directly stimulate $\mathrm{T}$ cell migration.

IL-15 is a recently identified cytokine that may be important in T cell migration (12-14). IL-15 stimulates T cells to assume a polarized morphology and increases $\mathrm{T}$ cell and natural killer (NK) cell migration (15-18). Other studies have shown that IL-15 shares many biologic activities with IL-2, including the ability to costimulate T cell and NK cell proliferation (13, $14,19)$. This may reflect the nature of the IL-15 receptor that consists of a $\beta$ chain shared with the IL-2 receptor, the common $\gamma$ chain shared with many cytokine receptors, and a specific IL-15 receptor $\alpha$ chain $(20,21)$. The functional role of other recently reported species of IL-15 receptors has not been clearly delineated (22).

Unlike IL-2, which is produced exclusively by $\mathrm{T}$ cells and NK cells, IL-15 mRNA was found to be produced by epithelial cells, monocytes, fibroblasts, dendritic cells, and activated $\mathrm{T}$ cell lines $(12,14,23)$. In addition, IL-15 was found to be produced in the heart, although extensive evaluation of the cell populations involved has not been carried out. In view of this

1. Abbreviations used in this paper: CFSE, 5-(and-6-)-carboxyfluorescein diacetate succinimidyl ester; EC, endothelial cell; ICAM, intercellular adhesion molecule; LFA, leukocyte function-associated antigen; MIP, macrophage inflammatory protein; NC, nitrocellulose; NK, natural killer; PDB, phorbol dibutyrate; PE, phycoerythrin; SCID, severe combined immune deficient. 
and the reported capacities of IL-15 to stimulate T cell migration and activation, we examined EC for the production of IL15 , and we attempted to determine the impact it may have on the transendothelial migration of $\mathrm{T}$ cells. These studies identify an important regulatory role of IL-15 in T cell extravasation. Results show that EC produce IL-15 mRNA and protein, and that endothelial IL-15 has paracrine and autocrine activities, by facilitating the transendothelial migration of $\mathrm{T}$ cells and modulating endothelial receptor expression, respectively. Moreover, IL-15 markedly increases T cell accumulation in rheumatoid synovial tissue engrafted into severe combined immune deficient (SCID) mice in vivo. These results identify IL15 derived from EC and perhaps other cells as a central regulator of the transendothelial migration of $\mathrm{T}$ cells.

\section{Methods}

Cell cultures. EC were isolated from individual human umbilical cord veins by collagenase digestion and cultured to third through fifth passages as described previously (4). T cells were isolated from normal human peripheral blood by density gradient centrifugation, adherent cell depletion, and passage over a nylon wool column, as described previously (4). To examine the impact of endothelial IL-15 on the transendothelial migration of $\mathrm{T}$ cells, $\mathrm{T}$ cells were assayed immediately after their purification, since freshly isolated $\mathrm{T}$ cells have been shown to adhere poorly to EC because of their expression of functionally inactive integrin adhesion receptors (4). In other experiments, the impact of exogenously added IL-15 on transendothelial migration was examined. For these studies, purified T cells were preincubated for $12-18 \mathrm{~h}$ at $37^{\circ} \mathrm{C}$ in RPMI 1640 containing $10 \%$ FCS, conditions which were shown previously to be sufficient to stimulate the activation of LFA-1 (4). Thus, whether IL-15 increased the migration of $\mathrm{T}$ cells beyond an effect resulting from adhesion receptor activation could be determined.

Nitrocellulose (NC) filter assay of the effect of IL-15 on transendothelial migration of $T$ cells. To determine the effect of IL- 15 on the transendothelial migration of $\mathrm{T}$ cells, a previously described assay to quantify transendothelial migration was used (4). In brief, EC $\left(7.5 \times 10^{5}\right)$ were cultured to confluence on the surfaces of NC filters $(5-\mu \mathrm{m}$ pore) obtained from Millipore Corp. (Bedford, MA), in medium $(0.5 \mathrm{ml})$ that contained RPMI plus $10 \% \mathrm{HS}, 24 \mu \mathrm{g} / \mathrm{ml}$ ECGS, and $50 \mu \mathrm{g} / \mathrm{ml}$ ascorbic acid. Subsequently, the EC were allowed to condition fresh medium ( $0.4 \mathrm{ml} \mathrm{RPMI}$ plus $10 \% \mathrm{HS} ; 4 \mathrm{~h}$ at $\left.37^{\circ} \mathrm{C}\right)$, after which time $50 \mu \mathrm{l}$ of either a mouse anti-human IL-15 mAb obtained from Genzyme (Cambridge, MA), a polyclonal goat anti-human IL-15 Ab, kindly provided by Dr. Mary Kennedy (Immunex Corp., Seattle, WA), or control mAb obtained from Sigma Chemical Co. (St. Louis, MO) was added to the wells $(20 \mu \mathrm{g} / \mathrm{ml}$ final concentration). After an additional incubation period $\left(30 \mathrm{~min}\right.$ at $\left.37^{\circ} \mathrm{C}\right)$ to allow the $\mathrm{Ab}$ to bind IL-15, freshly isolated T cells $\left(2 \times 10^{6} /\right.$ well $)$ were incubated in the wells for $4 \mathrm{~h}$ at $37^{\circ} \mathrm{C}$. Subsequently, the filters were recovered and the extent of $\mathrm{T}$ cell migration was quantitated, as previously described $(4,24)$. Other experiments examined the impact of IL-15 on the transendothelial migration of T cells. For these studies, T cells $\left(2.0 \times 10^{6} /\right.$ well $)$ that had been incubated at $37^{\circ} \mathrm{C}$ for $18 \mathrm{~h}$ to activate adhesion receptors were resuspended in RPMI that contained $0.6 \%$ BSA (RPMI/ BSA) in the absence or presence of the indicated concentrations of rIL-15 (kindly provided by Dr. Mary Kennedy or commercially obtained from R\&D Systems, Minneapolis, MN). Subsequently, the $\mathrm{T}$ cells were incubated with EC for $4 \mathrm{~h}$ at $37^{\circ} \mathrm{C}$. In some experiments, the effect of IL-15 on the migration of T cells through endothelium was compared with migration into plain NC filters that did not have an overlying EC monolayer, as previously described (4). The specificity of exogenous IL-15 on transendothelial migration also was examined by the addition of anti-IL-15 mAb $(10 \mu \mathrm{g} / \mathrm{ml}$; R\&D Systems $)$, or an isotype-matched control mAb (MOPC) obtained from Sigma
Chemical Co., to the T cells in the absence or presence of IL-15 immediately before the cells were added to the wells. Finally, the utilization of the adhesion receptors LFA-1 and ICAM-1 during transendothelial migration in the absence and presence of rIL-15 was determined by adding blocking anti-LFA-1 (CD11a; TS1/22) obtained from American Type Culture Collection (Rockville, MD), blocking anti-ICAM-1 (CD54; R6.5) kindly provided by Dr. Robert Rothlein (Boehringer Ingelheim, Ridgefield, CT), or isotypematched control mAb obtained from Sigma Chemical Co. All mAb were used at a final concentration of $20 \mu \mathrm{g} / \mathrm{ml}$.

Adhesion assay of $T$ cell binding to ICAM-1-coated substrates. The wells of 8-well chamber slides (Nunc Inc., Naperville, IL) were incubated $\left(60 \mathrm{~min}, 22^{\circ} \mathrm{C}\right)$ with purified soluble ICAM-1 $(5 \mu \mathrm{g} / \mathrm{well}$ in $0.3 \mathrm{ml}$ DPBS; kindly provided by Dr. Robert Rothlein), according to described procedures (25), or with BSA (2\% in PBS). Subsequently, the wells were rinsed several times with RPMI/BSA, and then freshly isolated T cells $\left(1.5 \times 10^{5}\right)$, in the absence or presence of rIL-15 (50 $\mathrm{ng} / \mathrm{ml}$ ) or phorbol dibutyrate (PDB; $50 \mathrm{ng} / \mathrm{ml}$ ) obtained from Sigma Chemical Co., were added to the wells. Similar results were obtained when nonspecific binding sites on the substrates were eliminated by incubation with BSA ( $2 \%$ ) or by rinsing in the RPMI/BSA solution. The specificity of the binding interaction was determined by blocking with anti-LFA-1, anti-ICAM-1, or isotype-matched control mAb. All $\mathrm{mAbs}$ were used at a final concentration of $20 \mu \mathrm{g} / \mathrm{ml}$. After an incubation period of $30 \mathrm{~min}$ at $37^{\circ} \mathrm{C}$, each well was washed twice with RPMI/BSA, fixed with formalin, permeabilized with $80 \%$ methanol, stained with hematoxylin, and the number of cells in each well was determined as previously described $(4,24)$ with a particle counter (Artek model 982; Dynatech Laboratories, Chantilly, VA). Photomicrographs of bound $\mathrm{T}$ cells were obtained using a light microscope (BHTU; Olympus, Lake Success, NY) equipped with a PM-10AD 35$\mathrm{mm}$ photomicrographic system.

Transwell assay of the effect of IL-15 on transendothelial migration. The ability of IL-15 to attract T cells across EC monolayers was examined using a previously described assay (5). In brief, in the wells of tissue culture-treated transwells $(24.5 \mathrm{~mm}, 3-\mu \mathrm{m}$ pore $)$ obtained from Costar Corp. (Cambridge, MA), EC $\left(3 \times 10^{6}\right)$ were cultured to confluence on hydrated type I collagen gels $(1.5 \mathrm{ml}, 50 \% \mathrm{vol} / \mathrm{vol})$ obtained from Vitrogen 100R (Celtrix, Palo Alto, CA). RPMI/BSA was added to the upper compartment of the transwells, and IL-15 (50 $\mathrm{ng} / \mathrm{ml}$ ) was added to the lower compartment. Subsequently, the IL-15 was allowed to diffuse into the collagen gels $\left(30 \mathrm{~min}\right.$ at $\left.37^{\circ} \mathrm{C}\right)$, after which $\mathrm{T}$ cells were incubated in the transwells for $4 \mathrm{~h}$ at $37^{\circ} \mathrm{C}$. At the end of the incubation period, nonadherent $\mathrm{T}$ cells and those that had migrated into the collagen gels were harvested as described previously (5).

Analysis of T cell or EC phenotype by flow cytometry. T cells in the initial and recovered populations were examined by flow cytometry as previously described (5), after staining with FITC and/or phycoerythrin (PE) labeled mAb for the expression of several surface receptors, including CD45RA (2H4, FITC), CD69 (Leu-23, PE), both purchased from Becton Dickinson (Mountain View, CA) or CD4 (Q4120, FITC), CD8 (UCHT-4, PE), CD45RO (UCHL-1, FITC), all purchased from Sigma Chemical Co. FITC or PE directly labeled isotype-matched irrelevant mouse $\mathrm{mAbs}$ were used as negative controls to verify the staining specificity of the experimental mAb. For direct staining, T cells were incubated with saturating concentrations of the indicated $\mathrm{mAb}$ for $30 \mathrm{~min}$ at $4^{\circ} \mathrm{C}$, washed three times with PBS containing $2 \%$ human serum and $0.1 \%$ sodium azide (PBS/HS), fixed with $1 \% p$-formaldehyde for $20 \mathrm{~min}$, and washed again, as described previously (5).

EC that had been cultured for 4 or $24 \mathrm{~h}$ in endothelial growth medium in the absence or presence of IL-15 $(50 \mathrm{ng} / \mathrm{ml})$ were harvested by chelation with EGTA $(0.5 \mathrm{mM})$, enumerated, and then examined by indirect staining, as previously described (5), with $\mathrm{mAb}$ against CD26, CD29, CD44 (IOA26, IOT29, and IOL44, respectively) all purchased from Immunotech (Westbrook, ME), CD31 and CD61 (MCB78.2 and CRC54, respectively), purchased from Caltag Labora- 
tories (San Francisco, CA), ICAM-1 (CD54, R6.5), CD62E, and CD106 (1.2B6 and 1G11, respectively), kindly provided by Dr. Dorian Haskard (RPMS Hammersmith Hospital, London, United Kingdom), CD62P (S12), kindly provided from Dr. Rod McEver (The University of Oklahoma Health Science Center, Oklahoma City, OK), or isotype-matched controls. For indirect staining, EC were incubated with control $\mathrm{mAb}$ or with saturating concentrations of the indicated $\mathrm{mAb}$ for $30 \mathrm{~min}$ at $4^{\circ} \mathrm{C}$, and then washed three times with PBS/HS, as described (5). Subsequently, the cells were counterstained with FITC-conjugated goat anti-mouse Ig obtained from Cappel Research Products (Durham, NC).

Intracellular levels of cadherin and $\mathrm{Bcl}-2$ were detected in $\mathrm{EC}$ after fixation with $1 \% p$-formaldehyde $\left(15 \mathrm{~min}, 22^{\circ} \mathrm{C}\right)$ and permeabilization with ice-cold methanol $\left(70 \%, 60 \mathrm{~min}, 4^{\circ} \mathrm{C}\right.$, in the dark). Subsequently, the cells were washed with PBS and indirect staining was carried out to measure cadherin using rabbit anti-pan-cadherin polyclonal Ab obtained from Sigma Chemical Co., or as a control, rabbit gamma globulins obtained from Miles Diagnostic (Kankakee, IL). Subsequently, the cells were counterstained with FITC-conjugated goat anti-rabbit Ig obtained from Life Technologies (Grand Island, NY). Direct staining was carried out to measure Bcl-2 levels in permeabilized EC as described above, using a FITC conjugated antihuman $\mathrm{Bcl}-2 \mathrm{mAb}$ (clone 124) obtained from Dako Corp. (Carpinteria, CA). Analysis of $\mathrm{T}$ cell or EC surface marker expression was performed by flow cytometry using a Becton Dickinson FACScan ${ }^{\circledR}$. Lymphocytes and EC were specifically analyzed by selective gating based on the parameters of forward and side scatter. The percentage of cells with green (FITC) and red (PE) fluorescence and the density of expression of specific determinants as estimated by the mean fluorescence intensity were calculated using the Becton Dickinson Lysis II program.

Flow cytometry also was used for analysis of the expression of endogenous intracellular and extracellular IL-15. For measurements of intracellular IL-15, harvested EC were fixed with $1 \% p$-formaldehyde $\left(15 \mathrm{~min}, 22^{\circ} \mathrm{C}\right)$, washed with PBS, and then permeabilized with icecold methanol $\left(70 \%, 60 \mathrm{~min}, 4^{\circ} \mathrm{C}\right.$, in the dark). Subsequently, the cells were washed with PBS and indirect staining was carried out, as previously described, using anti-IL-15 mAb $(0.5 \mu \mathrm{g} / \mathrm{ml})$, obtained from Genzyme or isotype-matched control mAb (5). Specificity of antiIL-15 mAb binding was demonstrated by adding rIL-15 $(25 \mathrm{ng} / \mathrm{ml})$ to the $\mathrm{mAb}$ before its addition to the cells. In certain assays, IL-15 expression by non-methanol-permeabilized cells also was examined by indirectly staining the cells with anti-IL-15 mAb, as described above. In addition, the binding of IL-15 to EC surfaces was studied by preincubating harvested EC with rIL-15 $(25 \mathrm{ng} / \mathrm{ml}$ in $5 \% \mathrm{HS}$, PBS, $0.1 \%$ $\mathrm{Na}$ azide, $22^{\circ} \mathrm{C}, 30 \mathrm{~min}$ ), and washing the cells before the addition of the anti-IL-15 mAb. In other experiments, EC were cultured in the presence of a combination of rTNF- $\alpha(200 \mathrm{U} / \mathrm{ml})$ and $\mathrm{rIFN}-\gamma(250 \mathrm{U} / \mathrm{ml})$ $\left(18 \mathrm{~h}, 37^{\circ} \mathrm{C}\right)$ before examination for the presence of intracellular and extracellular IL-15.

Analysis of IL-15 $\mathrm{mRNA}$ in EC. RNA was isolated and purified from $3 \times 10^{6} \mathrm{EC}$ and first-strand cDNA synthesized, as previously described (26). 3- $\mu$ l aliquots of the cDNA were added to a reaction mixture containing $\mathrm{MgCl}_{2}$, all four dNTPs obtained from Sigma Chemical Co., and specific primers for IL-15 (5' TTG TAT TGT AGG AGG CAT $3^{\prime}$ and $5^{\prime}$ AAG AGT TCA TCT GAT CCA AGG $3^{\prime}$ ), or as a control, glyceraldehyde-6-phosphate dehydrogenase (5' CTG GCG TAT TTT CAC CCC AC $3^{\prime}$ and 5' GGT TCA CCC ACT TGT AGG TG $3^{\prime}$ ). The sequences of the primer pairs for IL- 15 were selected using Gene Works software (release 2.3.1) obtained from Intelligenetics (Mountain View, CA). Subsequently, a second reaction mix containing Taq polymerase was added, as described previously (26). The final concentration of reagents was $50 \mathrm{mM} \mathrm{KCl}, 10 \mathrm{mM}$ Tris- $\mathrm{Cl}(\mathrm{pH}$ 9.0), $0.1 \%$ Triton $\mathrm{X}-100,1.5 \mathrm{mM} \mathrm{MgCl} 2,100 \mu \mathrm{M}$ each dNTP, $50 \mathrm{pmol}$ each primer, and $2 \mathrm{U} \mathrm{Taq}$ polymerase obtained from Promega Corp. (Madison, WI). Amplification was carried out with a cycle program of 30 cycles each for $5 \mathrm{~min}$ at $95^{\circ} \mathrm{C}, 1 \mathrm{~min}$ at $94^{\circ} \mathrm{C}, 30 \mathrm{~s}$ at $56^{\circ} \mathrm{C}$, and $1 \mathrm{~min}$ at $72^{\circ} \mathrm{C}$. Aliquots of the PCR products were analyzed on a $1.5 \%$ agarose gel and visualized by ethidium bromide staining. Subsequently, the PCR products were analyzed by Southern hybridization, as previously described, using a ${ }^{32} \mathrm{P}$-labeled probe (5' CGG AGA TGC AAG TAT TCA T $3^{\prime}$ ) selected with Gene Works software (5).

Immunohistochemistry. Synovial membranes of patients with rheumatoid arthritis were obtained from the knee or wrist at joint replacement surgery or synovectomy, frozen in liquid nitrogen, and $6-\mu \mathrm{m}$ frozen sections were prepared and acetone fixed as described previously (26). Subsequently, the tissue sections were analyzed for the presence of IL-15. All procedures were carried out at $22^{\circ} \mathrm{C}$, and each washing step was for $5 \mathrm{~min}$ in PBS. With the exception of the primary $\mathrm{mAb}$, all reagents were purchased from BioGenex (San Ramon, CA). Tissue sections were incubated (60 min) first with normal goat serum, and afterward ( $90 \mathrm{~min}$ ) with anti-IL-15 mAb or isotype-matched control $\mathrm{mAb}(20 \mu \mathrm{g} / \mathrm{ml})$, and then washed. The tissue was then treated (30 min) with hydrogen peroxide blocking solution, washed, incubated (15 min) with avidin blocking solution, washed, incubated (15 min) with biotin blocking solution, washed, and then incubated (20 min) with biotinylated goat anti-mouse Ig. The sections were then washed, incubated (20 min) with streptavidin-conjugated horseradish peroxidase, and washed two times (15 min each). Staining was visualized by incubation $(7 \mathrm{~min})$ with 3 -amino-9-ethyl carbazole. Finally, the tissue sections were washed and counterstained with hematoxylin obtained from Sigma Chemical Co. Photomicrographs were obtained

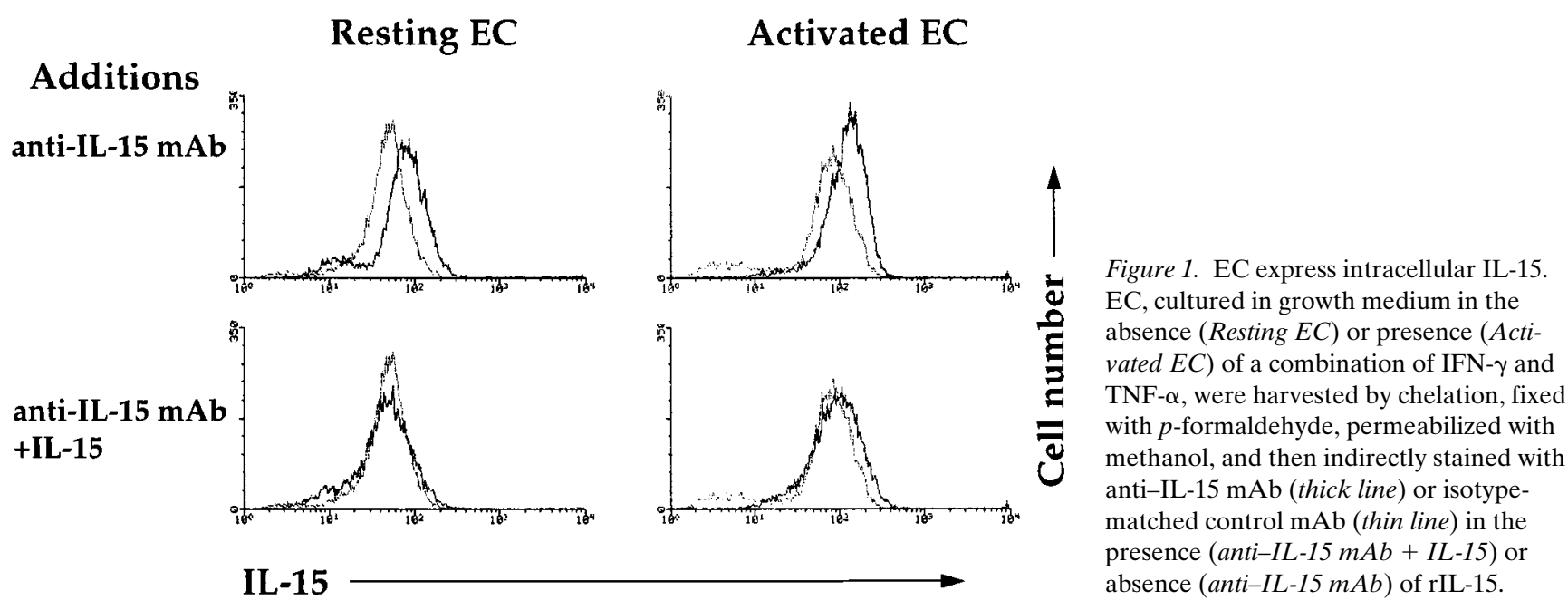


using an Olympus BHTU light microscope equipped with an Olympus PM-10AD 35-mm photomicrographic system.

SCID mouse/human rheumatoid arthritis model of T cell trafficking. Under ketamine/acepromazine anesthesia, small pieces $(\sim 2-3$ $\mathrm{mm}^{3}$ ) of rheumatoid synovium were surgically implanted subcutaneously into the dorsum of 4-6-wk-old CB17 SCID mice. After a 3-wk engraftment period, rIL-15 (1 $\mu \mathrm{g}$ in $0.1 \mathrm{ml} \mathrm{RPMI})$, or in separate animals RPMI alone $(0.1 \mathrm{ml})$, was injected subcutaneously into the graft. $16 \mathrm{~h}$ later, the injections were repeated and $\mathrm{T}$ cells purified by passage over a nylon wool column $\left(10^{7}\right.$ in $\left.0.1 \mathrm{ml} \mathrm{RPMI}\right)$ were injected into the tail vein. Before injection, $T$ cells were prelabeled with the fluorescent dye 5-(and-6-)-carboxyfluorescein diacetate succinimidyl ester (CFSE) obtained from Molecular Probes, Inc. (Eugene, OR). After a 16-h trafficking period, the grafts were harvested, frozen in liquid nitrogen, and $10-\mu \mathrm{m}$ cryostat sections were prepared. Subsequently, the frozen sections were air dried, fixed in ice-cold methanol, and then examined with an Axiophot inverted fluorescent microscope (Carl Zeiss, Thornwood, NY) interfaced with BDS imaging software obtained from Oncor (Gaithersburg, MD). The number of fluorescent cells in multiple sections was counted microscopically. Selected photographic images were exported to the Adobe Photoshop 4.0 software program where they were sized, mounted, and then printed.

\section{Results}

$I L-15$ is produced by $E C$. The initial experiments were carried out to determine whether IL-15 was a product of EC. As shown in Fig. 1, staining of permeabilized EC with a mAb against IL-15 and subsequent examination by flow cytometry demonstrated the presence of intracellular IL-15 in EC. This was observed regardless of the activation state of the EC (Fig. 1). Addition of rIL-15 to anti-IL-15 mAb inhibited detection of intracellular IL-15, demonstrating the specificity of the $\mathrm{mAb}$ staining. Subsequent analysis by PCR detected IL-15 mRNA in EC, confirming its production by this cell type (Fig. 2). In addition, IL-15 mRNA appeared to be increased when EC had been treated with IFN- $\gamma$ (Fig. 2).

Endothelial derived IL-15 stimulates the transendothelial migration of $T$ cells. As shown by the data of Fig. 3, addition of either monoclonal or polyclonal anti-IL-15 Ab to the incubations of EC with freshly isolated T cells inhibited transendothelial migration by 44.1 and $41.1 \%$, respectively, indicating that endogenous IL-15 was playing a role in transendothelial migration. The subsequent experiments were carried out to examine the mechanisms by which IL-15 increased transendothelial migration of $\mathrm{T}$ cells.

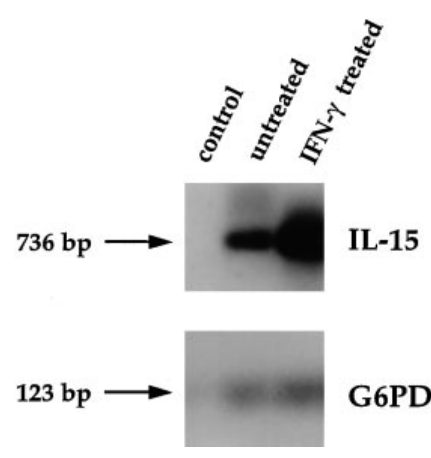

Figure 2. EC produce IL-15 mRNA. EC were cultured in the absence or presence of IFN- $\gamma$ for $24 \mathrm{~h}$ at $37^{\circ} \mathrm{C}$. Subsequently, the cells were chelated from the culture surfaces, RNA was isolated, RT-PCR was carried out to amplify the IL-15 cDNA, and then hybridized with a specific ${ }^{32} \mathrm{P}$-labeled probe. The PCR amplification of glyceraldehyde-6-phosphate dehydrogenase $(G 6 P D)$ cDNA was used to demonstrate that equal amounts of PCR product were loaded on the gel.

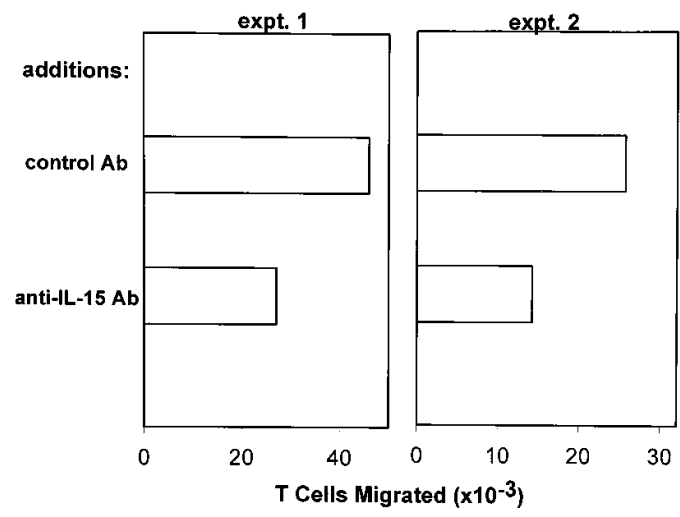

Figure 3. Endothelial IL-15 facilitates the transendothelial migration of T cells. Freshly isolated T cells were incubated with EC monolayers in the presence of goat anti-IL-15 polyclonal Ab (expt. 1), mouse anti-IL-15 mAb (expt. 2), or isotype-matched control Ab, after which time the number of migrating $\mathrm{T}$ cells was determined.

IL-15 stimulates $T$ cell binding to ICAM-1-coated substrates. The first experiments examined the impact of IL-15 on integrin adhesion molecule activity of freshly prepared T cells. Fig. 4 shows light micrographs of fresh $\mathrm{T}$ cell binding to ICAM-1 and BSA substrates. As can be seen, these T cells, which have inactive LFA-1 (4), bind poorly to ICAM-1. IL-15 not only increased $\mathrm{T}$ cell binding to ICAM-1, but it induced some of the cells to spread as well. PDB similarly stimulated T cell binding to and spreading on immobilized ICAM-1 (Fig. 4). In contrast, freshly prepared $\mathrm{T}$ cells bound poorly to BSA, a control substrate, regardless of stimulation with IL-15 or PDB (Fig. 4).

Fig. 5 presents data from experiments designed to quantitate binding of T cells to ICAM-1 and to identify the receptors used by IL-15-activated T cells to bind to ICAM-1. As previously shown (4), freshly isolated T cells bind poorly to ICAM-1, and those that bind do so largely in an LFA-1- and ICAM-1independent fashion (Fig. 5). In contrast, IL-15 increased T cell binding to ICAM-1 by more than fourfold (463.5 $\pm 109.8 \%$ mean \pm SEM of binding by control $\mathrm{T}$ cells in the presence of control $\mathrm{mAb}, n=3$ ), and the stimulated binding was inhibited by $\mathrm{mAb}$ against both LFA- $1 \alpha$ chain and ICAM-1 (48.2 \pm 17.7 and $28.5 \pm 3.4 \%$, respectively, mean \pm SEM of binding in the presence of isotype-matched control $\mathrm{mAb}, n=3$ ). For comparison, PDB, which has been shown to stimulate T cell utilization of LFA-1 (27), increased T cell binding to ICAM-1 to $562.7 \pm 131.8 \%$ of binding by control T cells (Fig. 5), and stimulated binding also was inhibited by mAb against both LFA-1 $\alpha$ chain and ICAM-1 (56.8 \pm 16.1 and $47.8 \pm 12.8 \%$, respectively, mean \pm SEM of binding in the presence of isotype-matched control $\mathrm{mAb}, n=3$ ).

IL-15 increases CD69 expression by $T$ cells. The next set of experiments addressed whether adhesion receptor activation was specifically stimulated or whether other $\mathrm{T}$ cell activation markers were also induced by IL-15. As shown in Fig. 6, the percentage of $\mathrm{T}$ cells expressing CD69 was modestly increased by stimulation with IL-15. Increased percentages of both CD4(+) CD69(+) and CD4(-) CD69(+) T cells were detected after IL-15 stimulation (Fig. 6). In contrast, IL-15 did 

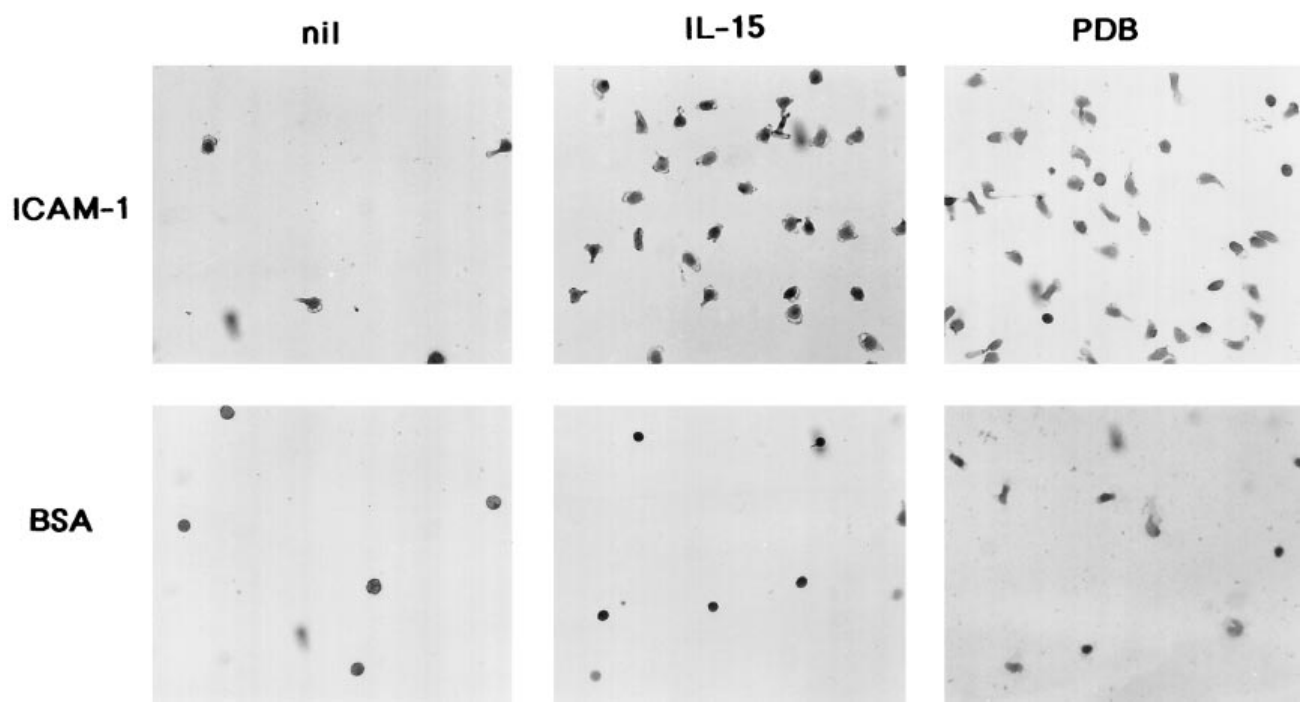

Figure 4. IL-15 induces T cell binding and spreading on ICAM-1-coated substrates.
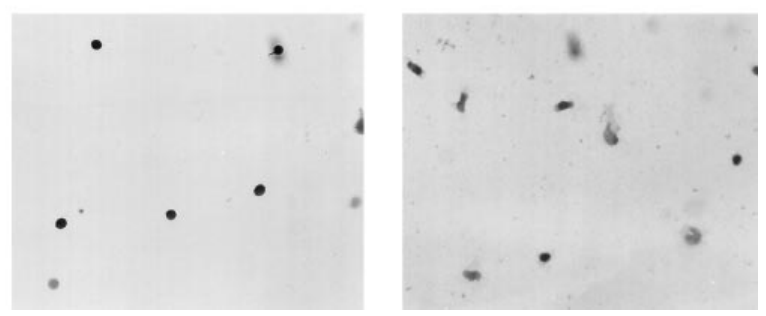
Freshly isolated $\mathrm{T}$ cells were incubated with ICAM-1- or BSAcoated substrates in the absence (nil) or presence of rIL-15 $(I L-15 ; 50 \mathrm{ng} / \mathrm{ml})$ or PDB $(P D B ; 50 \mathrm{ng} / \mathrm{ml})$, after which time the cells were fixed, stained, and photographed. $\times 200$.

not affect the percentage of $\mathrm{CD} 45 \mathrm{RO}(+)$ or CD45RA(+) $\mathrm{T}$ cells in the cultures (Fig. 6).

IL-15 increases the transendothelial migration of $T$ cells. To determine whether IL-15 affected transendothelial migration by mechanisms in addition to adhesion receptor activation, experiments were carried out examining the effect of exogenous IL-15 on migration of preincubated $\mathrm{T}$ cells, which expressed activated adhesion receptors (4). When placed below the EC monolayer, IL-15 (50 ng/ml) increased transendothelial migration to $145 \pm 7.3 \%$ of control $\mathrm{T}$ cell migration (mean \pm SEM, $n=5$ ) (Fig. 7). Neither raising the IL-15 concentration to $100 \mathrm{ng} / \mathrm{ml}$ nor lowering it to $25 \mathrm{ng} / \mathrm{ml}$ increased transendothelial migration further (data not shown). Other experiments demonstrated that IL-15 also stimulated transendothelial migration when it was added to $\mathrm{T}$ cells immediately before their incubation with EC. Thus, as shown in Fig. 7,

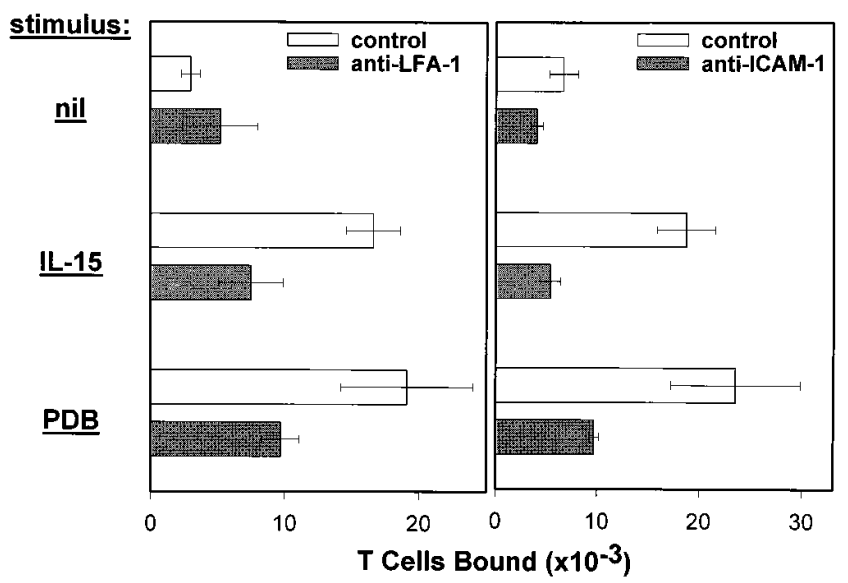

Figure 5. IL-15-stimulated T cell binding to ICAM-1-coated substrates is mediated by LFA-1 and ICAM-1. Freshly isolated T cells were incubated with sICAM-1-coated substrates in the absence (nil) or presence of rIL-15 $(I L-15 ; 50 \mathrm{ng} / \mathrm{ml})$ or PDB $(P D B ; 50 \mathrm{ng} / \mathrm{ml})$ plus $\mathrm{mAb}$ against LFA-1, ICAM-1 (shaded bars), or isotype-matched control (open bars), after which time the number of bound $\mathrm{T}$ cells was determined. transendothelial migration was increased by rIL-15 $(25 \mathrm{ng} / \mathrm{ml})$ to $157.5 \pm 11.3 \%$ of control $\mathrm{T}$ cell migration (mean $\pm \mathrm{SEM}, n=$ 3). Also shown in Fig. 7 is that IL-15 stimulated T cell migration regardless of the presence of an EC monolayer as IL-15 increased migration into plain NC filters to $178.3 \pm 4.1 \%$ of control $\mathrm{T}$ cell migration (mean $\pm \mathrm{SEM}, n=4$ ). Increasing the IL-15 concentration to $100 \mathrm{ng} / \mathrm{ml}$ had a negligible additional effect on T cell migration. The specificity of the activity of IL-15 was demonstrated using anti-IL-15 mAb. Thus, IL-15 increased T cell migration to $177 \%$ of control migration $(2.4 \times$ $10^{4}$ and $4.4 \times 10^{4}$ cells migrating in the absence and presence
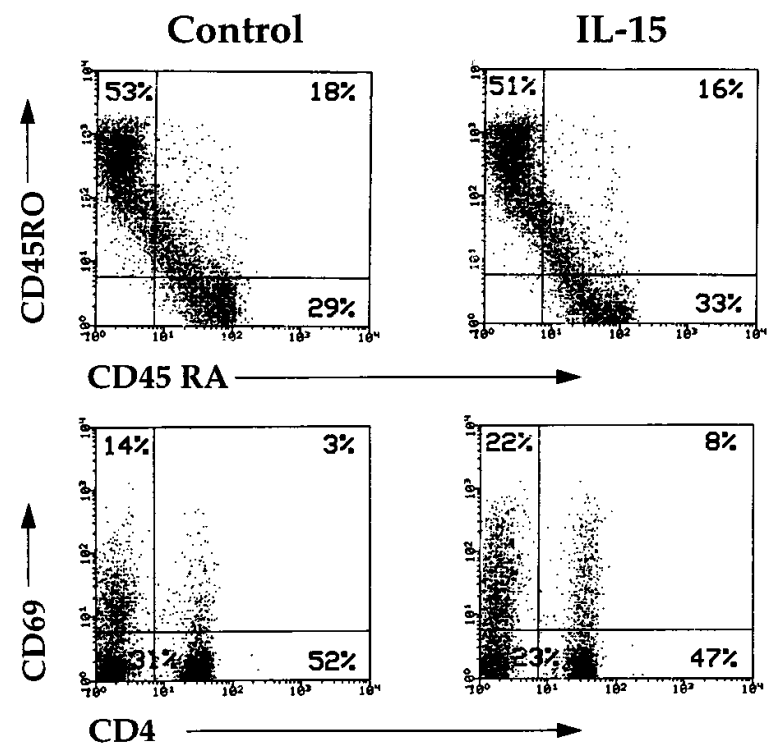

Figure 6. IL-15 increases CD69 expression but does not affect $\mathrm{CD} 45 \mathrm{RO}$ or CD45RA expression. T cells were cultured for $24 \mathrm{~h}$ at $37^{\circ} \mathrm{C}$ in the absence (Control) or presence of rIL-15 (IL-15). Subsequently, the cells were harvested and directly stained with CD45ROFITC- and CD45RA-PE-labeled mAb, CD4-FITC- and CD69-

$\mathrm{PE}-$ labeled $\mathrm{mAb}$, or isotype-matched control FITC- and PE-labeled $\mathrm{mAb}$, and then analyzed by flow cytometry. The percentage of the cells expressing the determinants is shown in each box. 


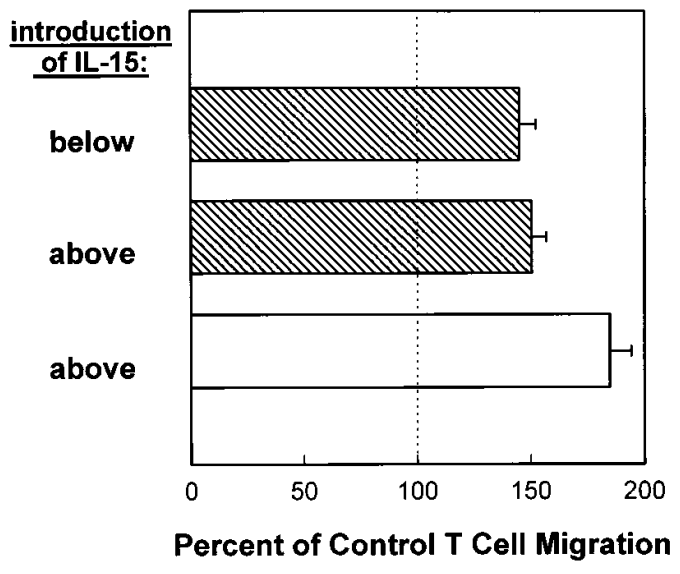

Figure 7. rIL-15 increases the transendothelial migration of T cells. T cells $\left(2 \times 10^{6}\right)$ were incubated in wells containing EC monolayers cultured on collagen gels or NC filters, or with plain NC filters, that did not have an overlying EC monolayer, in the absence or presence of rIL-15 (50 ng/ml). IL-15 was introduced into the incubations either by addition to the compartment below the collagen gel or above the NC filters. Results are expressed as the percentage of $\mathrm{T}$ cell migration in the presence of IL-15 divided by the number of migrated cells in control wells times 100 . Mean \pm SEM number of cells migrating through EC in the absence and presence of IL-15 of $116.7 \times 10^{3} \pm 2.7 \times 10^{3}$ and $184.5 \times 10^{3} \pm 16.9 \times 10^{3}$, respectively, and through plain NC filters of $41.4 \times 10^{3} \pm 17.0 \times 10^{3}$ and $72.1 \times 10^{3} \pm 28.3 \times 10^{3}$, respectively.

of IL-15, respectively), whereas migration in the presence of IL-15 plus anti-IL-15 mAb approximated control values. Neither anti-IL-15 mAb by itself nor the isotype-matched control $\mathrm{mAb}$ affected migration of adhesion receptor competent $\mathrm{T}$ cells (data not shown).

The phenotype of $\mathrm{T}$ cells migrating in the absence or presence of IL-15 was analyzed by flow cytometry. As shown by the data in Fig. 8, 25 and $57 \%$ of $\mathrm{T}$ cells migrating in the ab- sence and presence of IL-15, respectively, expressed the activation marker CD69. Also shown in Fig. 8 is that IL-15 stimulated a modest increase in the percentage of migrated $\mathrm{T}$ cells that were $\mathrm{CD} 8(+)$, and slightly decreased the percentage of migrated CD4 $(+)$ T cells. Moreover, the percentage of CD8(+) CD69(+) $\mathrm{T}$ cells appeared to be greater than the percentage of CD4(+) CD69(+) $\mathrm{T}$ cells in the migrating population. In contrast, when $\mathrm{T}$ cells migrated into collagen gels that did not have an overlying EC monolayer, IL-15 only minimally increased CD69 expression and did not influence the distribution of migrating CD4(+) and CD8(+) T cells (Fig. 9).

IL-15 stimulates the utilization of the adhesion receptor pair LFA-1/ICAM-1 for transendothelial migration. To confirm that IL-15-activated T cells used ICAM-1 interactions for transendothelial migration, experiments with blocking $\mathrm{mAb}$ were carried out. As shown by the data in Fig. 10, control transendothelial migration involved LFA-1-ICAM-1 interactions since it was inhibited by both anti-LFA- $1 \alpha$ chain and anti-ICAM-1 $\mathrm{mAb}(52.5 \pm 4.4$ and $47.4 \pm 6.5 \%$ of control migration, respectively, mean \pm SEM, $n=3)$. IL-15 stimulated transendothelial migration almost twofold $(194.0 \pm 17.0 \%$ of migration in the presence of control $\mathrm{mAb}$, mean $\pm \mathrm{SEM}, n=3$ ), and the increase was inhibited by mAb against LFA-1 and ICAM-1 (mean \pm SEM of $59.9 \pm 7.3$ and $49.1 \pm 9.7 \%$, respectively, of migration in the presence of isotype matched control $\mathrm{mAb}, n=3$ ).

IL-15 binds to EC and modulates the expression of some EC adhesion molecules, but not those involved in transendothelial migration. The next series of experiments focused on whether IL-15 altered the phenotype of the EC. After incubation with rIL-15, EC were found to have bound the cytokine, as detected with a specific anti-IL-15 mAb. As shown in Fig. $11(+I L-15)$, a subset of resting EC and all cytokine activated EC-bound rIL-15. The presence of membrane-associated IL-15 on resting EC in the absence of incubation with rIL-15 could not be detected (Fig. 11, Nil). However, surface expression of membrane-associated IL-15 was detected on EC that had been activated by a combination of TNF- $\alpha$ and IFN- $\gamma$ (Fig. 11, Nil).

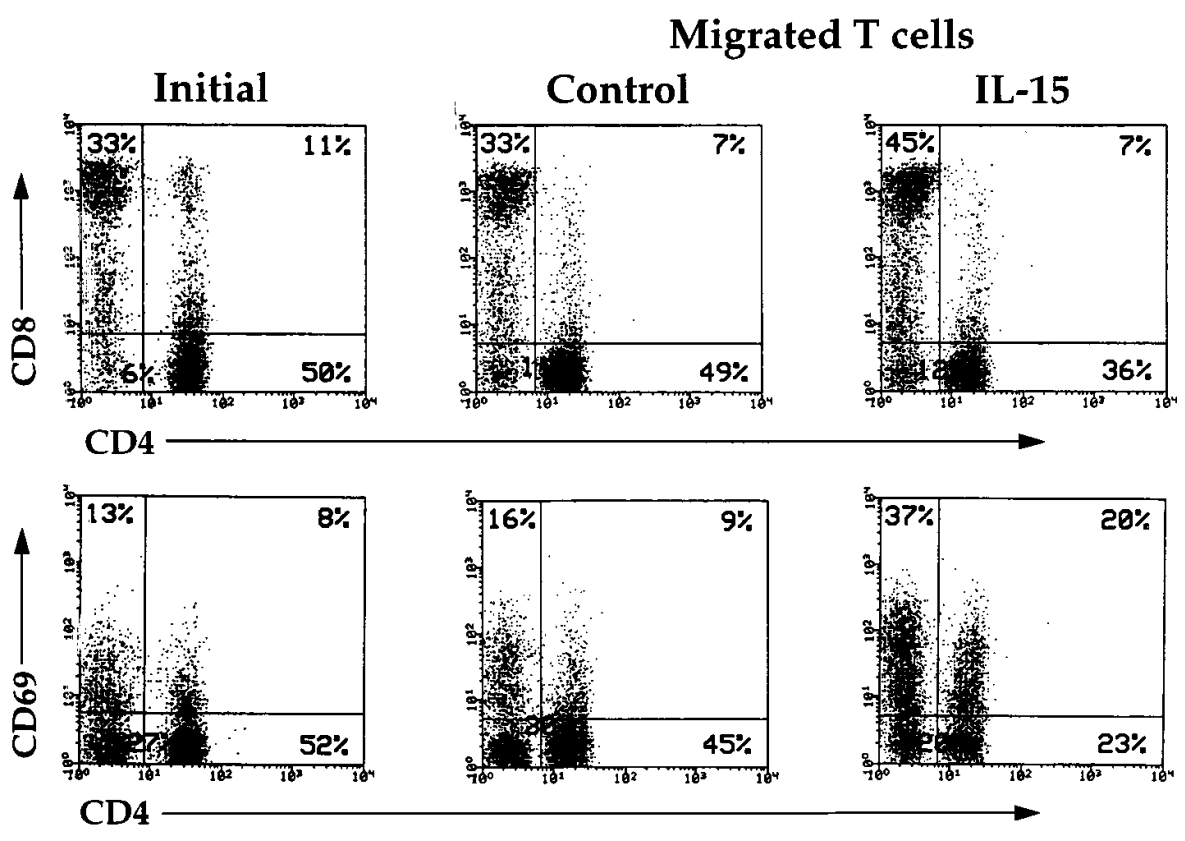

Figure 8. IL-15 stimulates the expression of CD69 on both CD4(+) and CD8(+) $\mathrm{T}$ cells that migrate through EC. T cells were incubated with EC monolayers that had been formed on collagen gels in transwells in the absence (Control) or presence $(I L-15)$ of rIL-15 $(50 \mathrm{ng} / \mathrm{ml})$ in the lower chamber. Migrated T cells were harvested after collagenase digestion of the collagen gel, directly stained with CD4-FITC- and CD8-PE-labeled mAb, CD4-FITC- and CD69-PE-labeled $\mathrm{mAb}$, or isotypematched control FITC and PE-labeled $\mathrm{mAb}$, and then analyzed by flow cytometry. Shown on the left is the expression of these determinants by $\mathrm{T}$ cells in the initial population. The percentage of the cells expressing the determinants is shown in each box. 


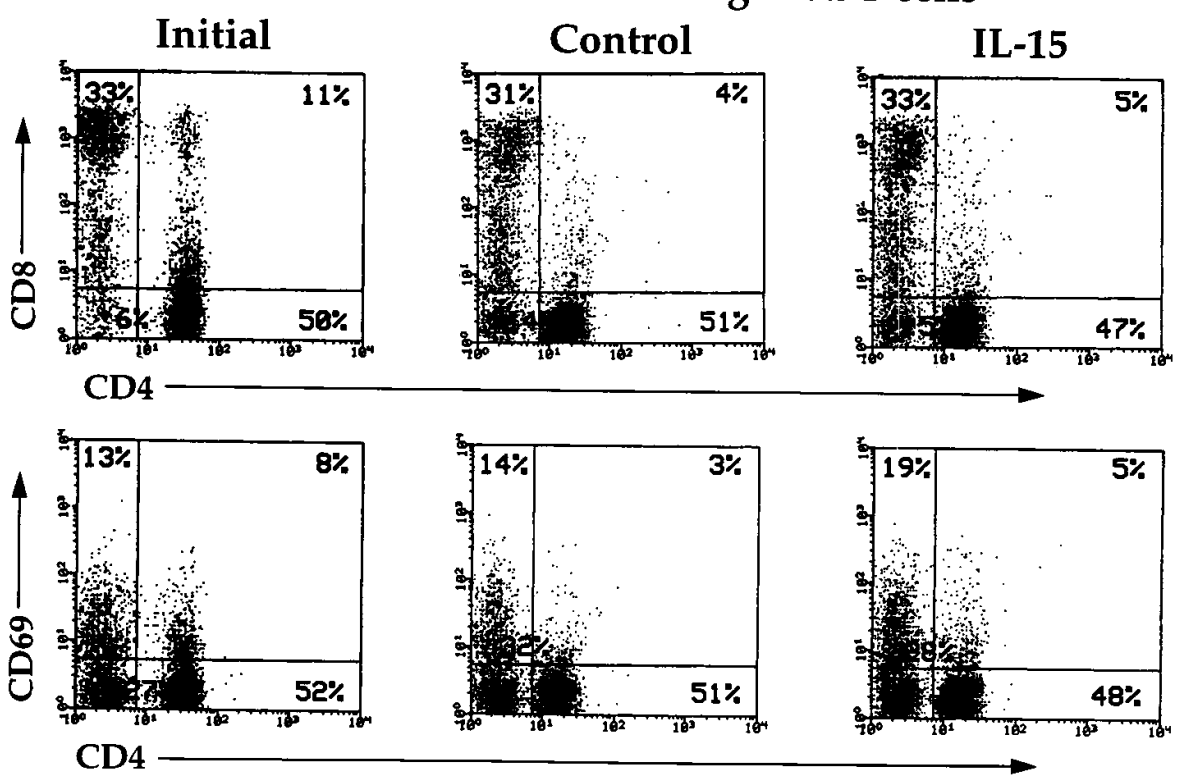

Migrated T cells

Figure 9. IL-15 minimally modulates the expression of CD69 on CD4(+) and CD8(+) T cells that migrate into plain collagen gels. T cells were incubated on hydrated collagen gels in transwells in the absence (Control) or presence of rIL-15 $(I L-15)$ in the lower chamber. Migrated T cells were harvested after collagenase digestion of the collagen gel, directly stained with CD4-FITC- and CD8-PE-labeled mAb, CD4-FITC- and CD69-PE-labeled $\mathrm{mAb}$, or isotype-matched control FITCand PE-labeled $\mathrm{mAb}$, and then analyzed by flow cytometry. Shown on the left is the expression of these determinants by $\mathrm{T}$ cells in the initial population. The percentage of the cells expressing the determinants is shown in each box.
Subsequent experiments determined the impact of IL-15 on EC adhesion molecule expression. Fig. 12 shows that IL-15 did not affect endothelial expression of CD31 or ICAM-1. Similarly, in data not shown, no differences were detected in the expression of CD26, CD29, CD44, CD61, CD62E, CD62P, or CD106 on EC cultured with IL-15 $(50 \mathrm{ng} / \mathrm{ml})$ for 4 or $24 \mathrm{~h}$ in comparison to control cells cultured in its absence. In contrast, IL-15 increased endothelial expression of cadherin as assessed by intracellular staining with a polyclonal $\mathrm{Ab}$ to the cytoplasmic domain of cadherin molecules (Fig. 12). Finally, IL-15 also appeared to downregulate Bcl-2 expression by EC (Fig. 12).

$I L-15$ is associated with EC in rheumatoid synovium. In the next series of experiments, the expression of IL-15 in vivo was examined. $6-\mu \mathrm{m}$ frozen sections of four different samples of rheumatoid synovium were examined for expression of IL-15. As shown by the light micrographs in Fig. 13, IL-15 was found

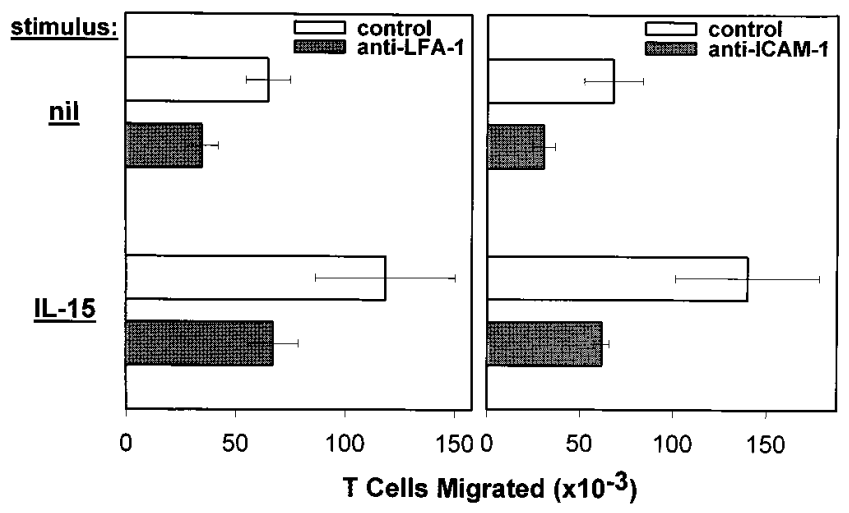

Figure 10. IL-15-stimulated transendothelial migration is mediated by LFA-1 and ICAM-1. T cells were incubated with EC monolayers in the absence (nil) or presence $(50 \mathrm{ng} / \mathrm{ml} ; I L-15)$ of rIL-15 plus $\mathrm{mAb}$ against LFA-1, ICAM-1 (shaded bars), or isotype-matched control (open bars), after which time the number of migrating $\mathrm{T}$ cells was determined. in association with EC in many vessels as well as with other cells scattered in the tissue. As can be discerned, IL-15 is localized both within EC as well as on EC surfaces. In addition, IL-15 positive blood vessels tended to be in the vicinity of developing inflammatory infiltrates (Fig. 13, $C-F$ ). Similar findings were noted in each synovial sample.

IL-15 increases the trafficking of $T$ cells into rheumatoid synovial tissue engrafted into SCID mice. In the final series of experiments the ability of IL- 15 to stimulate $\mathrm{T}$ cell trafficking in vivo was examined. When CFSE-labeled $\mathrm{T}$ cells were administered to SCID mice engrafted with rheumatoid synovium, a number of labeled cells appeared in transplanted inflammatory tissue. In contrast, few CFSE-labeled $\mathrm{T}$ cells accumulated in spleen, liver, or skin (data not shown). Of note, many of the labeled cells were found in association with blood vessels (Fig. $14 \mathrm{~A}$ ). Fig. $14 \mathrm{~B}$ also shows results from experiments in which $\mathrm{T}$ cell trafficking was examined after administration of IL-15 into the graft. As can be seen, the number of labeled $\mathrm{T}$ cells in the graft was increased severalfold in comparison to the accumulation that occurred in control SCID mice. Moreover, labeled cells were found diffusely distributed throughout the inflammatory tissue. No fluorescence was detected in rheumatoid synovium engrafted into SCID mice not challenged with CFSE-labeled T cells (data not shown).

\section{Discussion}

The vascular endothelium plays a critical role in the extravasation of T cells into perivascular tissues. Beyond promoting the transendothelial migration of $\mathrm{T}$ cells, these studies provide evidence that EC also elaborate IL-15, which stimulates integrin adhesion receptor activation and motility of migrating $\mathrm{T}$ cells. Moreover, the paracrine activity of IL-15 also leads to induction of early activation molecule expression by the migrating $\mathrm{T}$ cells. Although IL-15 could bind to EC, it does not appear to upregulate expression of adhesion molecules used by EC to promote transendothelial migration of T cells. However, IL-15 may have different autocrine activities inasmuch as it was 
Additions

Nil
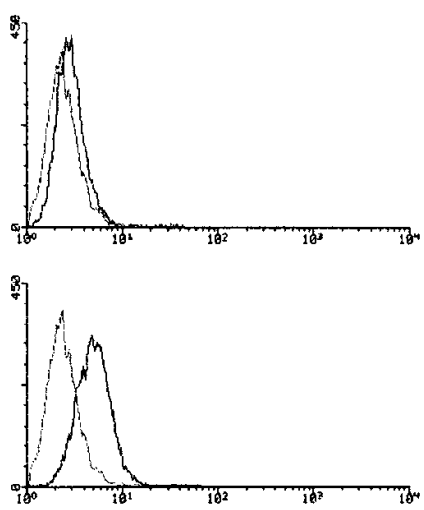

Activated EC
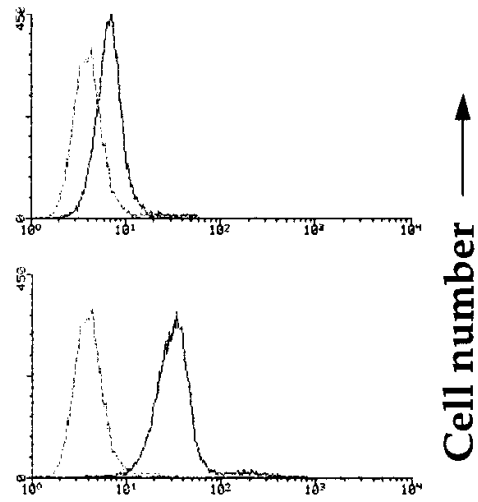

Figure 11. IL-15 is detected on the surfaces of activated, but not resting EC. EC, cultured in growth medium in the absence (Resting EC) or presence of a combination of IFN- $\gamma$ and TNF- $\alpha$ (Activated EC), were harvested by chelation, preincubated in the absence $(\mathrm{Nil})$ or presence $(+I L-15)$ of IL-15, fixed with $p$-formaldehyde, and then indirectly stained with anti-IL-15 mAb (thick line) or isotype-matched control $\mathrm{mAb}$ (thin line).

found to modulate expression of other EC-associated molecules.

By stimulating $\mathrm{T}$ cell motility and LFA-1 function, IL-15 activates critical behaviors of memory $\mathrm{T}$ cells that are required

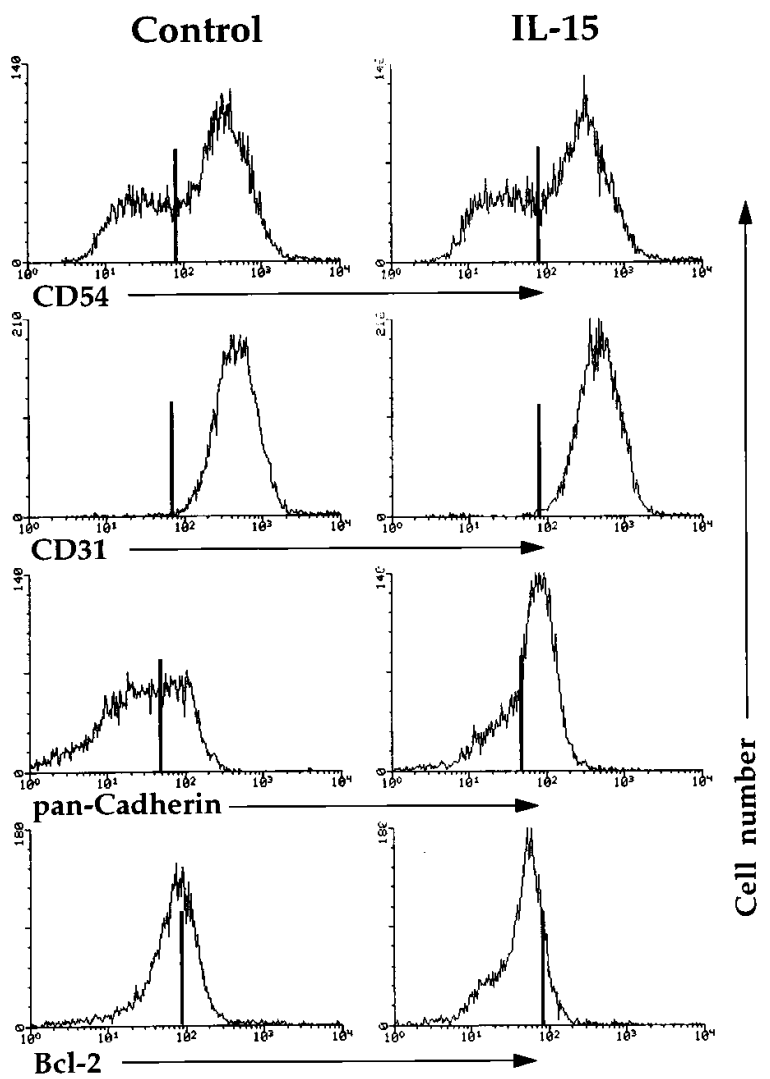

Figure 12. IL-15 modulates endothelial expression of cadherin and $\mathrm{Bcl}-2$, but not CD31 or ICAM-1. EC were treated for $24 \mathrm{~h}$ at $37^{\circ} \mathrm{C}$ in the absence (Control) or presence (IL-15) of IL-15, chelated from their culture surfaces, fixed with $p$-formaldehyde, and then stained with anti-CD31 mAb, anti-ICAM-1 mAb, or isotype-matched control $\mathrm{mAb}$, and then analyzed by flow cytometry. For examination of the expression of cadherin or Bcl-2 by EC, cells were permeabilized with methanol before indirect staining was carried out. for their transendothelial migration and recruitment to inflammatory sites. Generally, it has been held that for memory T cells to extravasate into tissue, it is necessary to induce the activity of integrin adhesion molecules $(28,29)$. Previous reports have shown that LFA-1 was an important mediator of the transendothelial migration of $\mathrm{T}$ cells $(3,4)$, and as the current data show, activation of LFA-1 on circulating $\mathrm{T}$ cells to bind ICAM-1 can occur as a result of the activity of IL-15. The ability of EC to elaborate IL-15 and the responsiveness of T cells to this cytokine by increasing motility and activating adhesion receptors may play a central role in the facilitation of $\mathrm{T}$ cell recruitment into inflammatory sites.

These studies also suggest that IL-15 nonspecifically enhances transendothelial migration of all $\mathrm{T}$ cell subsets with some bias toward $\mathrm{CD} 8(+) \mathrm{T}$ cells. This could relate to a greater sensitivity of CD8(+) T cells to the action of IL-15, perhaps because of greater IL-15 receptor density or enhanced signaling capability of IL-15 receptors on CD8(+) T cells. Even though CD8(+) T cells appear to be differentially affected by IL-15, the migration of both CD4(+) and CD8(+) T cells is significantly enhanced by IL-15. Thus, IL-15 appears to increase transendothelial migration of both major $\mathrm{T}$ cell subsets with minimal specificity. IL-15 not only increased transendothelial and LFA-1 activation, but also increased the expression of the early activation molecule, CD69, on both $\mathrm{T}$ cell subsets. CD69 expression was maximal when exogenous IL-15 was present and the migrating $\mathrm{T}$ cell population was examined. These data imply either that CD69 expression is maximal on the same memory $\mathrm{T}$ cell population that undergoes transendothelial migration or that the intimate contact between migrating T cells and EC costimulates CD69 expression along with IL-15. The current data do not permit a discrimination between these possibilities. However, the minimal induction of CD69 by IL-15 in the absence of EC is most compatible with the conclusion that EC are necessary to costimulate CD69 expression along with IL-15. This conclusion is compatible with previous findings that EC are very effective costimulators of $\mathrm{T}$ cell activation, although the role in costimulation of IL-15 responses has not been examined previously (30). EC are known to express a number of costimulatory molecules, including ICAM-1, VCAM-1, CD40, and CD40 ligand, that may be involved in inducing activation antigen expression by mi- 

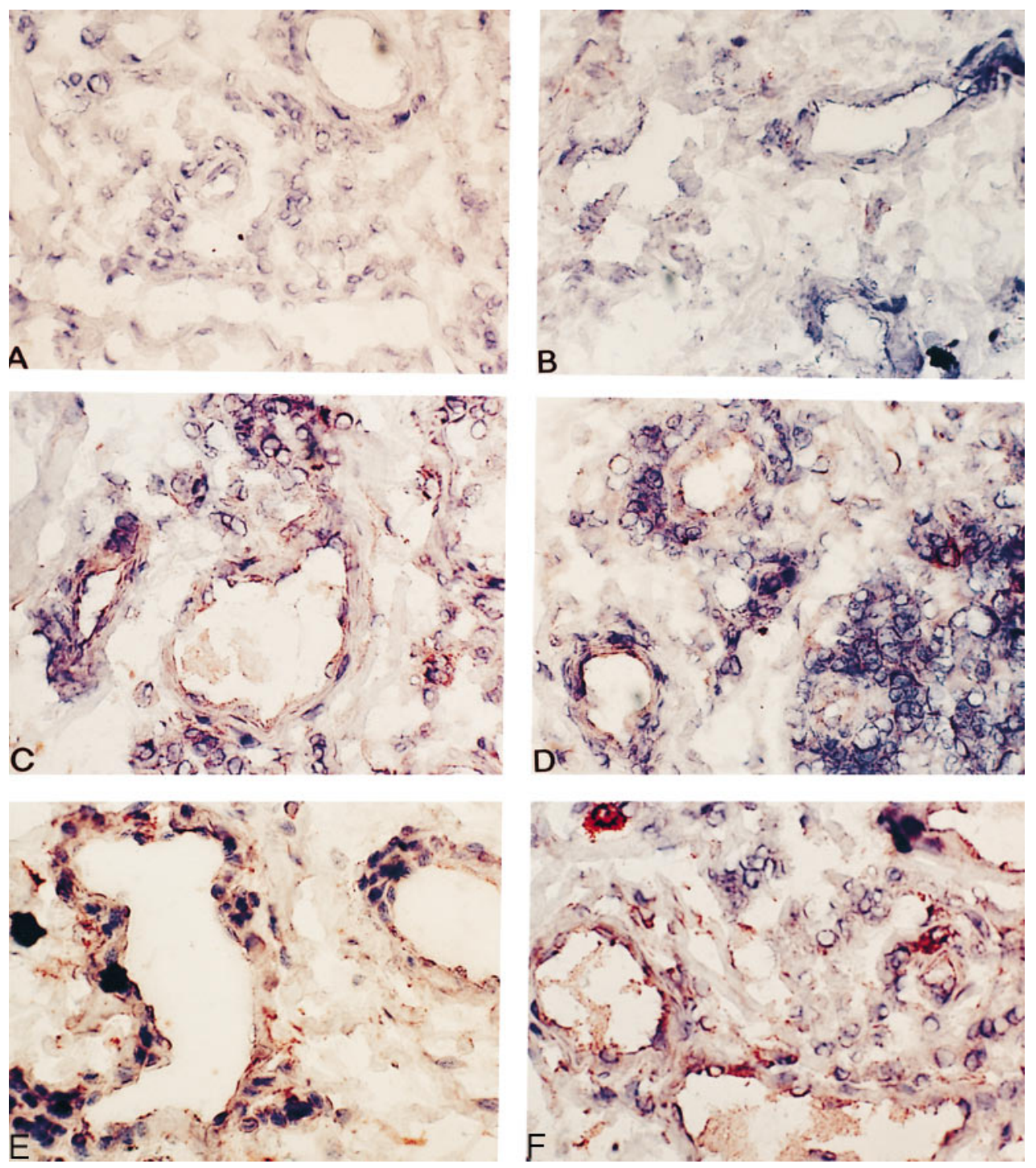

Figure 13. IL-15 is associated with EC in rheumatoid synovial membrane. 6- $\mu \mathrm{m}$ frozen sections of four patient samples of rheumatoid synovial tissue were examined by indirect immunoperoxidase for the expression of IL-15. Two of the samples are shown stained with isotype-matched negative control $\mathrm{Ab}$ $(A$ and $B$ ) and all four are shown stained with specific $\mathrm{mAb}$ against IL-15 $(C-F) . \times 200$.

grating $\mathrm{T}$ cells activated by IL-15 (31-34). The data indicate that IL-15 exerts several paracrine effects on $\mathrm{T}$ cells including stimulation of motility, upregulation of adhesion receptor function, and induction of activation antigen expression. Although IL-15 was shown recently to stimulate LFA-1-mediated NK cell binding to $\mathrm{EC}$ and to increase $\mathrm{T}$ cell motility (15-18), the current findings are the first to demonstrate the paracrine activities of endothelial IL-15 in the regulation of the transendothelial migration of $\mathrm{T}$ cells.

Recent reports have demonstrated the chemotactic activity of IL-15, when examined in assays carried out in the absence of the endothelium (15). However, our studies clearly show that the effect of IL-15 on T cell motility is more similar to chemokinesis than chemotaxis. Thus, IL-15 stimulated T cell motility regardless of the establishment of a gradient of activity. We cannot rule out the possibility that in the presence of EC, IL-15 binds to the endothelial surface and promotes migration in a chemotactic fashion, similar to mechanisms suggested for other chemokines, such as MIP- $1 \alpha$, although we and others have shown that binding to EC is not necessary for these chemotactic activities (5-7). Thus, as the current studies show, IL-15 stimulates T cell migration in the absence of the endothelium and in the absence of a chemotactic gradient. In this regard, the action of IL-15 on T cell motility is most likely to result from a chemokinetic impact of the cytokine.

These studies also show that IL-15 binds to EC, although the nature of the IL-15 receptor on EC has not been identified. In most cells, IL-15 has been reported to interact with a complex of molecules including the $\beta$ chain of the IL- 2 receptor, the common $\gamma$ chain that is shared by many receptors, and a novel IL-15 receptor $\alpha$ chain, the latter of which has been shown to be produced by EC $(20,21)$. As the current studies show, IL-15 delivers a signal to EC since modulation of endothelial VE-cadherin was observed. By itself, the IL-15 receptor $\alpha$ chain does not appear to deliver a transmembrane signal, although in the presence of a high concentration of IL-15 signaling was reported to occur through a complex formed only by the IL-2 receptor $\beta$ and common $\gamma$ chains together (35). Whether on EC, IL-15 binds to one or more of these molecules is currently unknown. However, we have not been able to detect the IL- 2 receptor $\beta$ chain on EC by flow cytometry (data not shown), making this contention unlikely. 

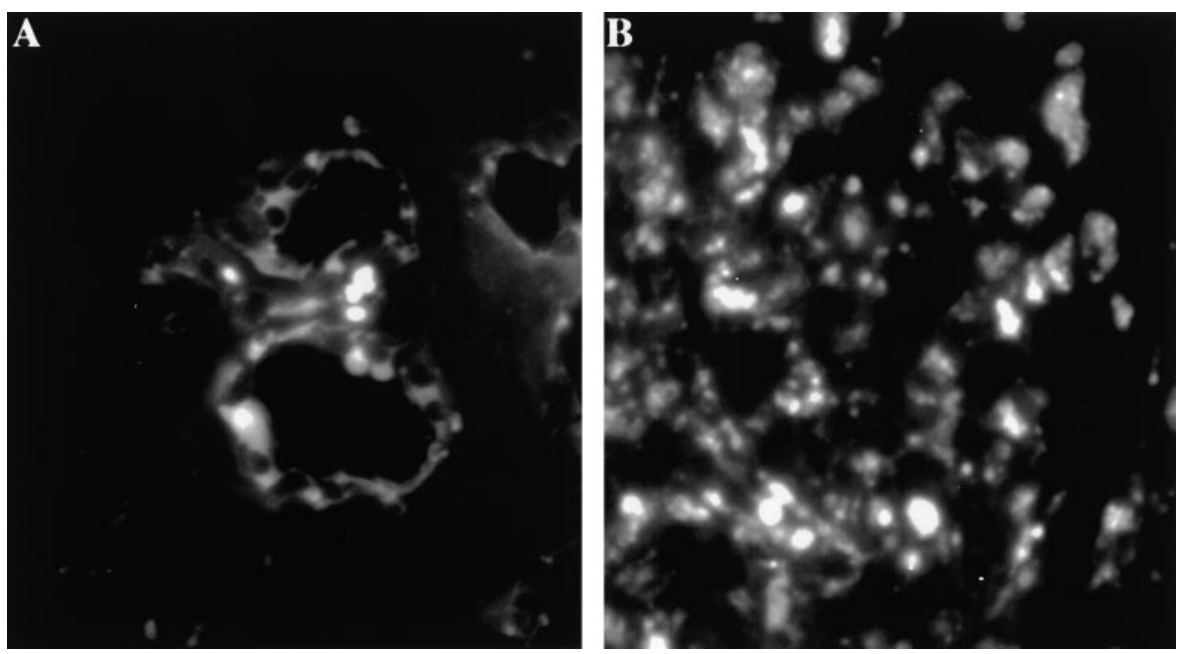

Figure 14. IL-15 increases T cell trafficking into rheumatoid synovial tissue grafts. Rheumatoid synovial tissue grafts were harvested from control $(A)$ or IL-15treated $(B)$ SCID mice $16 \mathrm{~h}$ after intravenous administration of CFSE- labeled $\mathrm{T}$ cells $\left(10^{7}\right)$. Images of $10-\mu \mathrm{m}$ frozen sections of tissue were obtained using a Zeiss Axiophot inverted fluorescent phase microscope with BDS imaging software. $\times 400$. The number of CFSE-labeled T cells in two sections of grafts harvested from IL-15-treated mice was more than eightfold greater than the number of CFSElabeled T cells in RPMI-treated mice ( $874 \pm 92$ vs. $105.5 \pm 0.5$ cells per section, respectively).

Part of the autocrine affects of IL-15 on EC appears to involve increased expression of VE-cadherin. In data not shown, we also found that the degree to which IL-15 increased cadherin expression was related to the confluence of EC. Thus, nonconfluent cultures expressed more VE-cadherin than subconfluent or confluent cells when stimulated by IL-15. This was observed using the pan-cadherin $\mathrm{Ab}$ as well as $\mathrm{mAb}$ against VE-cadherin (data not shown). At sites of endothelial damage, integrity of interendothelial junctions may be lost by disruption of homotypic VE-cadherin mediated interactions. At such times, IL-15 may play an important role in vessel repair by stimulating increased VE-cadherin production, and thereby restoring junctional integrity and organization.

Our findings also show EC constitutively express IL-15 intracellularly. Moreover, we found that activation of the endothelium by TNF- $\alpha$ and IFN- $\gamma$ stimulated the expression of endogenous IL-15 on EC surfaces. In certain T cell lines, IL-15 was reported to be transcribed but not translated (36). In contrast, in primary cultures of human umbilical vein EC IL-15 appears to be transcribed and translated. However, very small amounts of IL-15 protein are secreted. Thus, we were unable to find IL-15 in EC culture supernatants by ELISA even though it was clearly present and functionally active as described here. One possibility to explain this result could be that EC bind secreted IL-15 to membrane receptors or even produce a membrane form of IL-15 that is not freely secreted into the supernatant. Although there is no precedent for a membrane form of IL-15, recent studies have reported T cell membrane forms of IL-2 and IFN- $\gamma(37,38)$. A membrane form of IL-15 may explain the apparent resistance of the EC surfaceassociated IL-15 to chelation.

As these studies show, IL-15 is expressed in association with the endothelium of blood vessels in vivo at sites of chronic inflammation. At the light microscopic level, EC-associated IL-15 appears to be present both intra- and extracellularly. Particularly noteworthy is that most IL-15 positive blood vessels are prominent in areas of inflammatory cell infiltrates. Moreover, there was no IL-15 detected in the infiltrates, implying that endothelial IL-15 may be primarily involved in infiltrate formation. The role of IL-15 in vivo was confirmed in the SCID mouse-human RA model of inflammation. Several reported studies have used SCID mice for the investigation of the role of the inflammatory cells and synovial fibroblasts in models of autoimmunity (39-43). In these studies, SCID mice which lack functional $\mathrm{T}$ and $\mathrm{B}$ cells were successfully engrafted with human rheumatoid synovial tissue, without rejection or discernible graft-versus-host disease. Numerous blood vessels of varying size developed in the graft. These were of human origin, as evidenced by positive staining with $\mathrm{mAb}$ to human CD31 and human type IV collagen, and negative staining with MECA 32, a mAb reactive with murine endothelial determinants. Moreover, the engrafted synovium retained many other characteristics of rheumatoid synovium in situ, including the persistence of the inflammatory infiltrates. Administration of IL-15 into rheumatoid synovium grafts in SCID mice markedly increased $\mathrm{T}$ cell recruitment into the grafts. These results are consistent with the conclusion that IL-15 has an important physiologic role in $\mathrm{T}$ cell trafficking in vivo. Whether endogenously produced IL-15 accounted for the infiltration into control grafts is under investigation currently. Since little IL-2 has been found in rheumatoid synovium (44), only a few synovial T cells express CD25 (45), and yet all synovial T cells express an activated phenotype and are $\operatorname{CD} 69(+)(46)$, it is likely that locally produced IL-15 may play a critical role in promoting migration of memory $\mathrm{T}$ cells and their initial activation in rheumatoid synovium.

Finally, administration of IL-15 into rheumatoid synovium engrafted in SCID mice resulted in marked $\mathrm{T}$ cell infiltration into the tissue. Recent reports have indicated that administration of TNF- $\alpha$ into synovial tissue grafts in SCID mice also increased the number of $\mathrm{T}$ cells appearing in the graft (47). Moreover, it has been reported that IL-15 increases T cell production of TNF- $\alpha$ (48). Thus, perhaps part of the mechanism of persistent lymphocyte infiltration into sites of chronic inflammation involves elaboration of $\mathrm{TNF}-\alpha$ by migrating $\mathrm{T}$ cells which, in addition to increasing endothelial adhesion receptor expression (44), stimulates EC to elaborate IL-15. IL-15, on the other hand, would stimulate motility and LFA-1 activation of $T$ cells interacting with the vascular wall. By such a circuit, $\mathrm{EC}$ and $\mathrm{T}$ cells both would be critically involved in the recruitment and activation of T cells and EC, therefore, in the development and progression of chronic inflammation.

In summary, endothelial IL-15 stimulates the transendothelial migration of both $\mathrm{CD} 4(+)$ and $\mathrm{CD} 8(+) \mathrm{T}$ cells by in- 
ducing motility and adhesion receptor activation in these cells. Therefore, elaboration of IL-15 appears to be an important aspect of the mechanism EC use to facilitate T cell trafficking into perivascular tissue.

\section{Acknowledgments}

We gratefully acknowledge Dr. Kate Luby-Phelps for her imaging expertise, and Ellis "Skip" Lightfoot for his technical help in the immunohistochemistry experiments. We also thank Drs. Dorian Haskard, Mary Kennedy, Rod McEver, and Robert Rothlein for generously providing some of the reagents and antibodies used in these studies.

This work was supported by grants AR39169 and AR/OD420 from the National Institutes of Health.

\section{References}

1. Kavanaugh, A., and N. Oppenheimer-Marks. 1992. The role of the vascular endothelium in the pathogenesis of vasculitis. In Systemic Vasculitis: The Biological Basis. E. Carwile LeRoy, editor. Marcel Dekker, Inc.

2. Oppenheimer-Marks, N., and P.E. Lipsky. 1994. Transendothelial migration of T cells in chronic inflammation. Immunologist. 2:58-64.

3. Oppenheimer-Marks, N., L.S. Davis, D. Tompkins Bogue, J. Ramberg, and P.E. Lipsky. 1991. Differential utilization of ICAM-1 and VCAM-1 during the adhesion and transendothelial migration of human T lymphocytes. J. Immunol. 147:2913-2921.

4. Oppenheimer-Marks, N., L.S. Davis, and P.E. Lipsky. 1990. Human T lymphocyte adhesion to endothelial cells and trans-endothelial migration: alteration of receptor utilization relates to the activation status of both the $\mathrm{T}$ cell and the endothelial cell. J. Immunol. 145:140-148.

5. Brezinschek, R., P.E. Lipsky, P. Galea, R. Vita, and N. OppenheimerMarks. 1995. Phenotypic characterization of CD4(+) T cells that exhibit a transendothelial migratory capacity. J. Immunol. 154:3062-3077.

6. Woldemar Carr, M., S.J. Roth, E. Luther, S.S. Rose, and T.S. Springer. 1994. Monocyte chemoattractant protein 1 acts as a T-lymphocyte chemoattractant. Proc. Natl. Acad. Med. 91:3652-3656.

7. Roth, S.J., M. Woldemar Carr, and T.S. Springer. 1995. C-C chemokines, but not the $\mathrm{C}-\mathrm{X}-\mathrm{C}$ chemokines interleukin- 8 and interferon- $\gamma$ inducible protein-10, stimulate the transendothelial chemotaxis of T lymphocytes. Eur. J. Immunol. 25:3482-3488.

8. del Pozo, M.A., P. Sánchez-Mateos, M. Nieto, and F. Sánchez-Madrid. 1995. Chemokines regulate cellular polarization and adhesion receptor redistribution during lymphocyte interaction with endothelium and extracellular matrix. Involvement of cAMP signaling pathway. J. Cell Biol. 131:495-508.

9. Woldemar Carr, M., R. Alon, and T.S. Springer. 1996. The C-C chemokine MCP-1 differentially modulates the avidity of $\beta 1$ and $\beta 2$ integrins on T lymphocytes. Immunity. 4:179-187.

10. Gimbrone, M.A., Jr., M.S. Obin, A.F. Brock, E.A. Luis, P.E. Hass, C.A. Hébert, Y.K. Yip, D.W. Leung, D.G. Lowe, W.J. Kohr, et al. 1989. Endothelial interleukin-8: a novel inhibitor of leukocyte-endothelial interactions. Science. 246:1601-1603.

11. Li, Y.-S., Y.-J. Shyy, J.G. Wright, A.J. Valente, J.F. Cornhill, and P.E. Kolattukudy. 1993. The expression of monocyte chemotactic protein (MCP-1) in human vascular endothelium in vitro and in vivo. Mol. Cell. Biochem. 126: $61-68$.

12. Grabstein, K.H., J. Eisenman, K. Shanebeck, C. Rauch, S. Srinivasan, V. Fung, C. Beers, J. Richardson, M.A. Schoenborn, M. Ahdieh, et al. 1994. Cloning of a $T$ cell growth factor that interacts with the $\beta$ chain of the interleukin-2 receptor. Science. 264:965-968.

13. Giri, J.G., D.M. Anderson, S. Kumaki, L.S. Park, K.H. Grabstein, and D. Cosman. 1995. IL-15, a novel T cell growth factor that shares activities and receptor components with IL-2. J. Leukoctye Biol. 57:763-766.

14. Kennedy, M.K., and L.S. Park. 1996. Characterization of interleukin-15 (IL-15) and the IL-15 receptor complex. J. Clin. Immunol. 16:134-143.

15. Wilkinson, P.C., and F.Y. Liew. 1995. Chemoattraction of human blood T lymphocytes by interleukin-15. J. Exp. Med. 181:1255-1259.

16. Nieto, M., M.A. del Pozo, and F. Sánchez-Madrid. 1996. Interleukin-15 induces adhesion receptor redistribution in T lymphocytes. Eur. J. Immunol. 26:1302-1307.

17. McInnes, I.B., J. Al-Mughales, M. Feld, B.P. Leung, F.-P. Huang, R. Dixon, R.D. Sturrock, P.C. Wilkinson, and F.Y. Liew. 1996. The role of interleukin-15 in T-cell migration and activation in rheumatoid arthritis. Nat. Med. 2: $175-182$.

18. Allevana, P., G. Giardina, G. Bianchi, and A. Montovani. 1997. IL-15 is chemotactic for natural killer cells and stimulates their adhesion to vascular endothelium. J. Leukocyte Biol. 61:729-735.

19. Carson, W.E., J.G. Giri, M.J. Lindemann, M.L. Linett, M. Ahdieh, R.
Paxton, D. Anderson, J. Eisenmann, K. Grabstein, and M.A. Caligiuri. 1994. Interleukin (IL) 15 is a novel cytokine that activates human natural killer cells via components of the IL-2 receptor. J. Exp. Med. 180:1395-1403.

20. Giri, J.G., M. Ahdieh, J. Eisenman, K. Shanebeck, K. Grabstein, S. Kumaki, A. Namen, L.S. Park, D. Cosman, and D. Anderson. 1994. Utilization of the $\beta$ and $\gamma$ chains of the IL-2 receptor by the novel cytokine IL-15. EMBO (Eur. Mol. Biol. Organ.) J. 13:2822-2830.

21. Giri, J.G., S. Kumaki, M. Ahdieh, D.J. Friend, A. Loomis, K. Shanebeck, R. DuBose, D. Cosman, L.S. Park, and D.M. Anderson. 1995. Identification and cloning of a novel IL-15 binding protein that is structurally related to the $\alpha$ chain of the IL-2 receptor. EMBO (Eur. Mol. Biol. Organ.) J. 14 3654-3663.

22. Tagaya, Y., J.D. Burton, Y. Miyamoto, and T.A. Waldmann. 1996. Identification of a novel receptor/signal transduction pathway for IL-15/T in mast cells. EMBO (Eur. Mol. Biol. Organ.) J. 15:4928-4939.

23. Tagaya, Y., R.N. Bamford, A.P. DeFilippis, and T.A. Waldmann. 1996. IL-15: a pleiotropic cytokine with diverse receptor/signaling pathways whose expression is controlled at multiple levels. Immunity. 4:329-336.

24. Oppenheimer-Marks, N., and M. Ziff. 1988. Lymphocyte migration through endothelial cell monolayers: augmentation by gamma interferon. Cell. Immunol. 114:307-323.

25. Rothlein, R., E.A. Mainolfi, M. Czajkowski, and S.D. Marlin. 1991. A form of circulating ICAM-1 in human serum. J. Immunol. 147:3788-3793.

26. Brezinschek, R.I., H.-P. Brezinschek, A. Lazarovits, P.E. Lipsky, and N. Oppenheimer-Marks. 1996. Expression of the beta7 integrin by human endothelial cells. Am. J. Pathol. 149:1651-1660.

27. Dustin, M.L., and T.A. Springer. 1989. T-cell receptor cross-linking transiently stimulates adhesiveness through LFA-1. Nature. 341:619-624.

28. Oppenheimer-Marks, N., and P.E. Lipsky. 1995. Leukocyte adhesion and leukocyte traffic in rheumatoid arthritis. In Mechanisms and Models in Rheumatoid Arthritis. B. Henderson, J.C.W. Edwards, and E.R. Pettipher, editors. Academic Press Ltd., San Diego, CA. 221-239.

29. Sharar, S.R., R.K. Winn, and J.M. Harlan. 1995. The adhesion cascade and anti-adhesion therapy: an overview. Springer Semin. Immunopathol. 16 359-378.

30. Geppert, T.D., and P.E. Lipsky. 1989. Antigen presentation by cells that are not of bone marrow origin. Regional Immunol. 2:60-71.

31. van Seventer, G.A., Y. Shimizu, K.J. Horgan, and S. Shaw. 1990. The LFA-1 ligand ICAM-1 provides an important costimulatory signal for T cell receptor-mediated activation of resting T cells. J. Immunol. 144:4579-4586.

32. Damle, N.K., and A. Aruffo. 1991. Vascular cell adhesion molecule 1 induces T-cell antigen receptor-dependent activation of CD4+ T lymphocytes. Proc. Natl. Acad. Sci. USA. 88:6403-6407.

33. Karmann, K., C.C. Hughes, J. Schechner, W.C. Fanslow, and J.S. Pober 1995. CD40 on human endothelial cells: inducibility by cytokines and functional regulation of adhesion molecule expression. Proc. Natl. Acad. Sci. USA. 92: 4342-4346.

34. Mach, F., U. Schönbeck, G.K. Sukhova, T. Bourcier, J.-Y. Bonnefoy, J.S. Pober, and P. Libby. 1997. Functional CD40 ligand is expressed on human vascular endothelial cells, smooth muscle cells, and macrophages: implications for CD40-CD40 ligand signaling in atherosclerosis. Proc. Natl. Acad. Sci. USA. 94:1931-1936

35. de Jong, J.L.O., N.L. Farner, M.B. Widmer, J.G. Giri, and P.M. Sondel 1996. Interaction of IL-15 with the shared IL-2 receptor $\beta$ and $\gamma \mathrm{c}$ subunits. $J$. Immunol. 156:1339-1348.

36. Onu, A., T. Pohl, H. Krause, and S. Bulfone-Paus. 1997. Regulation of IL-15 secretion via the leader peptide of two IL-15 isoforms. J. Immunol. 158: 255-262.

37. Kaplan, D.R., C.A. Bergmann, D. Gould, and B. Landmeier. 1988. Membrane-associated interleukin 2 epitopes on the surface of human T lymphocytes. J. Immunol. 140:819-826.

38. Assenmacher, M., A. Schefoold, J. Schmitz, J.A.S. Checa, S. Miltenyi, and A. Radbruch. 1996. Specific expression of surface interferon- $\gamma$ on interferon- $\gamma$ producing T cells from mouse and man. Eur. J. Immunol. 26:263-267.

39. Rendt, K.E., T.S. Barry, D.M. Jones, C.B. Richter, S.S. McCachren, and B.F. Haynes. 1993. Engraftment of human synovium into severe combined immune deficient mice. J. Immunol. 151:7324-7336.

40. Sack, U., H. Kuhn, J. Ermann, R.W. Kinne, S. Vogt, D. Jungmichl, and F. Emmrich. 1993. Synovial tissue implants from patients with rheumatoid arthritis cause cartilage destruction in knee joints of SCID.bg mice. J. Rheumatol. 19:10-16.

41. Geiler, T., J. Kriegsmann, G.M. Keyszer, R.E. Gay, and S. Gay. 1994. A new model for rheumatoid synovial tissue and normal human cartilage into SCID mice. Arthritis Rheum. 37:1664-1671.

42. Jorgensen, C., I. Couret, I. Hellier, C. Bologna, F. Canovas, J. Brochier, T. Reme, and J. Sany. 1996. In vivo migration of radiolabeled lymphocytes in rheumatoid synovial tissue engrafted in SCID mice: implication of $\beta 2$ and $\beta 7$ integrin. J. Rheumatol. 23:32-35.

43. Muller-Ladner, U., J. Kriegsmann, B.N. Franklin, S. Matsumoto, T. Geiler, R.E. Gay, and S. Gay. 1996. Synovial fibroblasts of patients with rheumatoid arthritis attach to and invade normal human cartilage when engrafted into SCID mice. Am. J. Pathol. 140:1607-1615. 
44. Lipsky, P.E., L.S. Davis, J.J. Cush, and N. Oppenheimer-Marks. 1989. The role of cytokines in the pathogenesis of rheumatoid arthritis. Springer Semin. Immunopathol. 11:123-162.

45. Cush, J.J., and P.E. Lipsky. 1988. Phenotypic analysis of synovial tissue and peripheral blood lymphocytes isolated from patients with rheumatoid arthritis. Arthritis Rheum. 31:1230-1238.

46. Kohem, C.L., R.I. Brezinschek, P.E. Lipsky, and N. OppenheimerMarks. 1996. Enrichment of differentiated CD27- memory T cells in rheuma- toid arthritis blood, synovial fluid and tissue. Arthritis Rheum. 39:844-854

47. Jorgensen, C., J. Courets, F. Canova, C. Bologna, J. Brochier, T. Reme, P. Lipsky, and J. Sany. 1996. Mononuclear cell retention in rheumatoid synovial tissue engrafted in SCID mice is up-regulated by TNF- $\alpha$ and mediated through ICAM-1. Clin. Exp. Immunol. 106:20-25.

48. McInnes, I.B., B.P. Leung, R.D. Sturrock, M. Field, and F.Y. Liew. 1997. Interleukin-15 mediates T cell-dependent regulation of tumor necrosis factor- $\alpha$ production in rheumatoid arthritis. Nat. Med. 3:189-195. 